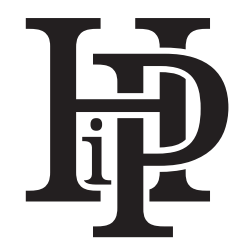

Historia i Polityka

Nr 35(42)/2021, ss. 147-162

www.hip.umk.pl (c) $\underset{\mathrm{ar}}{\Theta}$

ISSN 1899-5160, e-ISSN 2391-7652

DOI: http://dx.doi.org/10.12775/HiP.2021.009

Krzysztof GŁOW I A K

Centrum Kształcenia Torus, Dębica, Polska

\title{
Stosunek Polaków do przyjmowania uchodźców przed i w warunkach europejskiego kryzysu migracyjnego
}

\author{
Attitude of Poles toward Receiving Refugees Before and in the Conditions \\ of the European Migration Crisis
}

\section{- Abstrakt •}

Artykuł zwraca uwagę na to, że europejski kryzys migracyjny wywołał w Polsce istotne zmiany nastrojów społecznych, polegające na wzroście postaw niechęci i wrogości wobec migrantów spoza Europy. Państwa Europy Zachodniej, poddane od wielu dekad procesom wielokulturowości, są skłonne do przyjmowania imigrantów i integracji, podczas gdy w Polsce temat jest trudny ze względu na brak codziennych kontaktów Polaków z przedstawicielami państw spoza Europy, co powoduje zwiększony poziom obaw oraz zmniejsza szansę asymilacji przybyszów z zagranicy.

Słowa kluczowe: migracja; uchodźcy; kryzys migracyjny; postawy wobec uchodźców

\section{- Abstract •}

The article draws attention to the fact that the European migration crisis caused significant changes in the social mood in Poland, consisting in an increase in the attitudes of hostility towards migrants from outside Europe. Western European countries, which have been subjected to multicultural processes for many decades, are willing to accept immigrants and integrate, while in Poland the subject is difficult due to the lack of daily contacts between Poles and representatives from outside Europe, which causes an increased level of fears and anxieties and reduces the chance for assimilation of newcomers from abroad.

Keywords: migration; refugees; migration crisis; attitudes towards refugees

\section{Wstęp}

Jedną z podstawowych swobód jest wolność przemieszczania się. Prawo to daje obywatelom możliwość wjazdu i wyjazdu z państwa w granicach uregulowanych prawnie i niezależnych od ingerencji władz państwowych ani żadnych instytucji i osób. Prawo do wolności przemieszczania się umożliwia człowiekowi realiza- 
cję zamierzonych celów, jakimi są opuszczenie miejsca dotychczasowego pobytu i wjazd na terytorium innego państwa w celu zamieszkania w nim. Istotą tak pojmowanej wolności przemieszczania się jest swoboda przekraczania granic państwowych (Olszewska-Łabędź, 2018, s. 369).

Zamiarem artykułu jest przedstawienie zmian postaw Polaków do przyjmowania uchodźców i udzielania im pomocy wobec potencjalnych imigrantów spoza Europy z pozytywnych sprzed kryzysu migracyjnego i ukazanie uwarunkowań stopniowego spadku pozytywnego nastawienia wobec przyjmowania uchodźców z bliskiego wschodu. Artykuł składa się z dwóch części. Pierwsza część zajmuje się kwestią stosunku Polaków do przyjmowania uchodźców przed europejskim kryzysem migracyjnym. Druga natomiast traktuje o stosunku Polaków do przyjmowania uchodźców w warunkach europejskiego kryzysu migracyjnego.

Autor jako metodę badawczą stosuje analizę danych zastanych. Podstawę tejże analizy stanowią: raporty i komunikaty z badań sondażowych CBOS oraz innych wybranych podmiotów badawczych, dokumenty, publikacje naukowe w postaci książek i artykułów w polskich czasopismach naukowych, które stanowią dzieła starsze, jak i najnowsze zajmujące się przedmiotem podejmowanej w artykule problematyki. W pracy wykorzystano 23 opracowania w postaci książek i artykułów.

\section{Stosunek Polaków do przyjmowania uchodźców przed europejskim kryzysem migracyjnym}

Do 1989 r. Polska była krajem emigracyjnym. Polityka migracyjna stanowiła wypadkową polityki państwa zmierzającej do kontrolowania tego procesu i za jego pomocą wzmacniania ustroju niedemokratycznego i kształtowania struktury narodowościowej państwa. Przebieg i następstwa II wojny światowej miały decydujący wpływ na kształt terytorialny i ustrój polityczny Polski, a tym samym na politykę migracyjną. Wojenna i powojenna rzeczywistość zadecydowała o znaczącej dynamice wędrówek Polaków, ale w przeważającej mierze nie miały one dobrowolnego charakteru, a wynikały z decyzji politycznych ówczesnych władz. Polska nie była krajem „przyjmującym” imigrantów, ale „wysyłającym”. W latach 1945-1989 przybyło do Polski zaledwie 20-30 tysięcy uchodźców. Najpierw uchodźcy polityczni z Grecji, a w latach 70. XX w. uchodźcy z Chile (Hryniewicz, 2005, s. 27). Okres do 1989 r. po masowych powojennych migracjach możemy określić mianem „zamknięcia imigracyjnego” - ściślej reglamentacji wyjazdów i wjazdów, w których dużą rolę odgrywały czynniki polityczne i gospodarcze (Łodziński, 2012, s. 49). 
Okres 1989-2000 to czas, w którym państwo polskie borykało się z problemami związanymi z transformacją ustrojową i nie podejmowało długofalowych działań integracyjnych. Wszelkiego rodzaju inicjatywy integracyjne były sporadyczne, podejmowane ad hoc i wynikały z doraźnych potrzeb. Główny ciężar prowadzenia działań integracyjnych spoczywał na organizacjach pozarządowych (Wach, 2012, s. 348).

Zainicjowany w 1989 r. proces transformacji społeczno-politycznej stanowił przełom w procesach migracyjnych w Polsce. Demokratyczne przemiany polityczne spowodowały otwarcie granic Polski oraz zniesienie ograniczeń wyjazdowych i przyjazdowych zarówno dla obywateli polskich, jak i dla cudzoziemców. Stworzyło to jakościowo nową sytuację migracyjną w Polsce. Rzeczpospolita zyskała status państwa emigracyjno-imigracyjnego. W stosunku do lat poprzednich zwiększyła się wielokrotnie liczba osób przyjeżdżających i wyjeżdżających z Polski. Przy czym należy zauważyć, że dla wielu cudzoziemców stanowiła jedynie punkt na mapie ich podróży na północ lub zachód Europy. Niewielu w początkowym okresie transformacji decydowało się na pozostanie na naszym terytorium. Między innymi dlatego, że Polska nie miała odpowiedniej bazy infrastrukturalnej, a zasoby finansowe państwa były ograniczone. Ponadto Polska w pierwszej połowie XX w. była postrzegana stereotypowo, jako kraj mało atrakcyjny zwłaszcza socjalnie dla imigrantów (Podgórzańska, 2015, ss. 238-239).

Wraz z poprawą sytuacji społeczno-ekonomicznej w Polsce, wzrosła atrakcyjność Polski wśród różnych grup imigrantów (Pędziwiatr, 2014, s. 135). Systematycznie, w miarę poprawy sytuacji gospodarczej w Polsce, rosło zainteresowanie naszym państwem jako krajem osiedlenia dla wszystkich obcokrajowców niezależnie od przyczyny migracji. Nie było to jednak na tyle silne, by Polska z kraju emigracyjnego stała się krajem imigracyjnym. W kontekście nowej sytuacji migracyjnej w Polsce po 1989 r. imigranci przestali być w Polsce zjawiskiem marginalnym i egzotycznym (Fehler i in., 2017, s. 160).

Z biegiem czasu, wraz z nasileniem się skali napływu imigrantów do Polski, zjawisko to stało się również przedmiotem głośnej dyskusji medialnej. Zauważyć jednak należy, że działo się to każdorazowo, gdy Polska wskutek rozwoju sytuacji na arenie międzynarodowej zagrożona była wzrostem napływu imigrantów. O imigrantach dyskutowano wówczas, gdy jakieś zwarte grupy uchodźców przybywały do Polski. Tak było w latach 90. ubiegłego stulecia, gdy do Polski trafiali uchodźcy z Jugosławii, Czeczenii, Kosowa, nie wywoływało to jednak społecznego zainteresowania (Leszkowicz-Baczyński, 2018, s. 35).

Jeśli chodzi o Polskę, pierwsze badania na ten temat przyjmowania osób poszukujących schronienia ze względu na wojnę i prześladowania w krajach pochodze- 
nia zainicjowane zostały na początku okresu transformacyjnego, a ich realizatorem było Centrum Badania Opinii Społecznej. Stosunek Polaków do obcych w Polsce dotyczył wtedy obywateli krajów dawnego ZSRR, Jugosławii i Rumunii. Ponad połowa Polaków akceptowała wówczas czasowe przyjęcie uchodźców - 55\%, przy czym ich pobyt stały akceptowali nieliczni - 3\%. Jednocześnie co trzecia osoba - 34\% - optowała za odsyłaniem uchodźców do innych państw, miejsca ich pochodzenia lub też sugerowała obojętność wobec nich.

Przyjęcie przez Polskę w 1991 r. Konwencji Genewskiej dotyczącej statusu uchodźców wraz z Protokołem Nowojorskim sprawiło, że staliśmy się od początku lat 90. ubiegłego wieku krajem przyjmującym uchodźców oraz realizującym zobowiązania międzynarodowe $\mathrm{w}$ tej dziedzinie. W połowie tej dekady prasa i media pisały o zjawisku uchodźstwa w Europie i w naszym kraju ze względu na jego nowość oraz ówczesny kryzys uchodźczy. Później nie był to temat pierwszorzędny, ze względu na małą liczbę podań o przyznanie statusu uchodźcy oraz znikomą liczbę osób, które ten status otrzymały (Łodziński, 2012, s. 159).

Tematyka ta wraz z migracyjną nie była praktycznie poruszana na dużą skalę w Polsce w żadnej kampanii medialnej od 1989 r. Sporadycznie wspominano o niej przy okazji debat parlamentarnych dotyczących przyjmowania ustawy o cudzoziemcach 1997 r. oraz kolejnych jej nowelizacji, a także otwarcia granic i wejścia Polski do strefy Schengen (Łodziński, 2012, s. 159).

Zainicjowany w Polsce lat 90. klimat otwierania się na Europę, ówczesna linia polityki zagranicznej i związane z nią tendencje do integracji z Unią, były jednak równocześnie źródłami coraz bardziej pozytywnego, empirycznie udokumentowanego postrzegania imigrantów. Stąd też od 1997 r. odnotować trzeba poprawę stosunku do uchodźców. W badaniach OBOP zadano m.in. pytanie: „Czy pozwolił(a)by Pan(i) bawić się własnym dzieciom z dziećmi o innym kolorze skóry”. W 1988 r. odpowiedziało na nie twierdząco 89\%Polaków, a dekadę później 92\%. Z kolei na pytanie: „Czy zaprosił(a)by Pan(i) osobę o innym kolorze skóry do własnego domu np. na kolację?” odpowiedzi w analogicznych okresach stanowiły kolejno 84\% i 89\% (Leszkowicz-Baczyński, 2018, s. 35).

Wyniki badań dotyczących postaw wobec uchodźców prowadzonych w naszym kraju w latach 1992-2008 stanowią tło dla zmian, które zaszły w 2015 r. W badaniach tych Polacy odpowiadali na pytanie o pomoc dla uchodźców: jakich rozwiązań wobec uchodźców oni oczekują. W 1992 r., kiedy w Polsce pojawiła się stosunkowo niewielka liczba uchodźców, ponad połowa badanych, tj. 55\%, skłonna była zaakceptować osiedlanie się ich w naszym kraju na dłuższy czas. Jednak w latach następnych stosunek badanych do tej kwestii uległ zasadniczej zmianie. Bardzo spadła akceptacja zezwalania uchodźcom na osiedlanie się w Pol- 
sce na dłuższy czas, wzrosło natomiast poparcie na rzecz odsyłania ich z powrotem do państw, z których przyjechali. W 2000 r. odsetek badanych, którzy za najwłaściwsze uważają odsyłanie ich z powrotem, wyniósł $25 \%$ i był niższy niż odsetek akceptujących pozostawienie tych osób w Polsce na dłuższy czas, który wyniósł 36\% badanych. Z kolei w 2008 r. otwartość wobec uchodźców wyrażająca się przyzwoleniem na ich osiedlanie się w naszym kraju na stałe był już na wysokim poziomie 67\% badanych (Łodziński, 2012, s. 160).

Najbardziej odrzucające postawy wobec uchodźców zostały odnotowanie w 1996 r. Ich przyczyny można doszukiwać się w utożsamianiu ich z imigrantami ekonomicznymi lub nielegalnymi oraz obecnych wówczas silnych obawach związanych z napływem cudzoziemców z krajów byłego ZSRR, mogących przyczynić się do wzrostu przestępczości. Wówczas też blisko połowa badanych, która wyniosła 48\%, postulowała odsyłanie ich do krajów pochodzenia. W 2000 r. nastąpiło zmniejszenie niechęci wobec uchodźców do $25 \%$ badanych postulujących odsyłanie ich do krajów pochodzenia i wzrost przyzwolenia na umożliwienie im osiedlenia się w Polsce czasowo do $36 \%$ badanych oraz na stałe do $15 \%$ badanych. Trwało to do 2008 r. (Łodziński, 2012, s. 160).

Opinie na temat uchodźców były wyrabiane przede wszystkim nie na podstawie osobistych doświadczeń, lecz pochodziły ze stereotypowych wyobrażeń. Według sondażu TNS OBOP z lipca 2008 r. 12\% ogółu badanych zadeklarowało, że poznało w Polsce uchodźcę, a zdecydowana większość $88 \%$ badanych Polaków nigdy nie miała szans się z nim spotkać. Ten odsetek badanych, którzy mieli bezpośredni kontakt z uchodźcami, nie zmienił się na przestrzeni ostatnich lat. Według przywołanych badań większość Polaków prawidłowo identyfikowała termin „uchodźca” jako osobę, która opuściła swój kraj w obawie przed prześladowaniami, a dla połowy badanych określenie to oznaczało także uciekinierów z terenów kraju objętego wojną. Ponad $2 / 3$ respondentów traktowało uchodźców jako osoby migrujące z przyczyn ekonomicznych, a ponadto jako „repatriantów” lub osoby należące do mniejszości narodowych (Ząbek, Łodziński, 2008, ss. 413-414). Polacy pytani o zakres pomocy dla uchodźców zgadzali się powszechnie na zapewnienie im pobytu w ośrodkach dla uchodźców, za co miała być odpowiedzialna administracja państwa. Zgoda na inne formy pomocy uchodźcom była już mniejsza, zwłaszcza gdy chodziło o zapewnienie im świadczeń związanych z edukacją i zatrudnieniem. Można powiedzieć, że obecność uchodźców w Polsce była wówczas postrzegana i oceniana przez pryzmat samego społeczeństwa polskiego (Łodziński, 2012, s. 161).

Wejście Polski do UE i wymagania dostosowania polskiego ustawodawstwa do acquis communautaire UE odegrało ważną rolę w rozwoju polskiej polityki 
migracyjnej. Konieczne było dostosowanie prawa krajowego do zasad porozumienia z Schengen i wprowadzenie jego przepisów, podjęcie środków mających na celu umocnienie zabezpieczeń wschodniej granicy Polski, która stała się zewnętrzną granicą UE, wprowadzenie dla obcokrajowców zza wschodniej granicy i dostosowywanie systemu azylowego i polityki do prawa unijnego. (Balicki, 2012, ss. 204-205).

W dniu 20 lipca 2011 r. został przyjęty przez Międzyresortowy Zespół ds. Migracji dokument Polityka migracyjna Polski - stan obecny i postulowane dziatania stwierdzał, żeby traktować w sposób preferencyjny w zakresie pobytu i pracy wybrane grupy cudzoziemców, takie jak:

a) osoby pochodzenia polskiego,

b) studentów, naukowców, absolwentów polskich uczelni,

c) cudzoziemców prowadzących działalność gospodarczą,

d) imigrantów zarobkowych o potrzebnych kwalifikacjach,

e) obywateli państw członkowskich UE, członków ich rodzin,

f) członków rodzin obywateli polskich oraz cudzoziemców osiadłych w Polsce,

g) małoletnich, w szczególności pozostawianych bez opieki (Balicki, 2012, s. 207).

Dane pochodzące sprzed kryzysu emigracyjnego w Europie ujawniają, że poprzedzające go przekonania Polaków dotyczące emigrantów były przynajmniej korzystne, a wręcz uznać je można za umiarkowanie pozytywne (Leszkowicz-Baczyński, 2018, s. 36).

\section{Stosunek Polaków do przyjmowania uchodźców w warunkach europejskiego kryzysy migracyjnego}

Okres od 2015 r. to czas, kiedy to wyraźny wpływ na podejmowane decyzje polityczne odegrał „kryzys migracyjny”, który choć nie dotknął bezpośrednio Polski, to wywołał powszechną debatę na temat migracji i integracji cudzoziemców. W 2015 r. zaobserwować można nie tylko zmianę retoryki w kwestiach polityki migracyjnej i integracyjnej, ale też wycofanie się z realizacji dotychczasowych dokumentów strategicznych w tym zakresie z założeń dokumentu Polityka Migracyjna Polski - stan obecny i postulowane dziatania. Rok 2015 stał się obecnie cezurą w polityce integracyjnej i zapoczątkował nowe podejście do kwestii integracji cudzoziemców (Wach, 2012, s. 348).

W całym 2015 r. toczyła się w Polsce debata publiczna o udziale Polski w pomocy na rzecz rozwiązywania kryzysu migracyjnego. Początkowo skupiła się ona 
wokół przyjmowania chrześcijan z Syrii. Nikt wówczas nie negował publicznie konieczności ich przyjmowania, a kontrowersje budziła jedynie idea sprowadzania samych tylko chrześcijan z tego kraju. Latem 2015 r. dyskusja na temat przyjmowania uchodźców przybrała nowe oblicze, związane z nowym napływem imigrantów do Europy, kierujących się głównie do Niemiec i Austrii oraz krajów skandynawskich. Komisja Europejska próbowała rozwiązać ten problem m.in. przez relokację uchodźców przybyłych do krajów Europy Południowej pomiędzy kraje członkowskie Unii. Rząd polski zdecydował w lipcu 2015 r. o przyjęciu około 2 tysięcy uchodźców, a we wrześniu 2015 r. następnej grupy ponad 5 tysięcy osób w ramach systemu relokacji (Łodziński, 2017, s. 156).

W Polsce emigracja ludzi młodych to proces masowy, niepozostający bez wpływu na strukturę demograficzną kraju oraz rynek pracy. Wzrost odsetka ludności w wieku nieprodukcyjnym, depopulacja regionów czy ogólny spadek liczby ludności to zjawiska w dużym stopniu warunkowane odpływem Polaków za granicę. Depopulacja oraz starzenie się społeczeństwa to problemy, których symptomy są odczuwalne nie tylko na poziomie systemowym, lecz także na poziomie jednostkowym, w codziennym życiu. Niekorzystne prognozy demograficzne, w tym wzrastający wskaźnik obciążenia demograficznego, pozwalają przypuszczać, że procesy te mogą wywoływać wśród Polaków różnego rodzaju obawy, zwłaszcza o utrzymanie dotychczasowego statusu społeczno-ekonomicznego. W celu odwrócenia trendów demograficznych konieczne jest zwiększenie napływu ludności (Dutka, 2017, ss. 68-69).

Ważnym wydarzeniem wpływającym na postawy wobec uchodźców i sposoby rozwiązywania kryzysu migracyjnego był atak terrorystyczny dokonany w Paryżu 13 listopada 2015 r., w którym zginęło 130 osób, a jeden z zamachowców przyjechał do Europy jako uchodźca posługujący się paszportem syryjskim (Łodziński, 2017, s. 156).

Ataki terrorystyczne spowodowały głębokie zmiany w naszej opinii publicznej dotyczące gotowości przyjmowania imigrantów. W ciągu 6 miesięcy nastąpił szybki spadek o 30\% wysokiego poziomu deklarowanych pozytywnych postaw wobec uchodźców oraz silny wzrost negatywnych nastawień wobec nich. Z dotychczasowego tematu humanitarnego stali się oni problemem społecznym, z uwagi na wyzwanie w zakresie zapewnienia bezpieczeństwa przed możliwymi zagrożeniami terrorystycznymi. Wydaje się, że wspomniane odwrócenie postaw wobec uchodźców miało w dużym stopniu związek ze społecznym odbiorem w naszym kraju zjawiska "kryzysu migracyjnego” w Europie. Przybrało ono u nas formę „paniki moralnej" (Zielińska, 2004, ss. 162-164). Udział mediów w informowaniu na temat rozwoju tego zjawiska powoduje, że poruszany problem jest nie tylko 
rzeczywisty, ale może ich nawet osobiście dotknąć, co skutkuje także wzrostem „publicznej nerwowości” z tego powodu (Łodziński, 2017, s. 157).

Wiedza o obawach społecznych, ich uwarunkowaniach i źródłach jest łatwa do uzyskania oraz niezbędna i pożądana do podejmowania decyzji w różnych obszarach działalności. Z łatwością jej pozyskania wiąże się nie tylko możliwość rozpowszechniania, lecz także niwelowania i kreowania obaw, co jest stosowane z różnym skutkiem i intencją (Dutka, 2017, ss. 67-68).

Zagrożenia atakami terrorystycznymi dowodzą, że obawa przed nimi przejawia się wśród społeczeństwa na różne sposoby. Nie są to jedynie reakcje emocjonalne, takiej jak doświadczenie lęku czy złości, ale złożone procesy mające dalszy wpływ na funkcjonowanie ludzi w społeczeństwie. Odczuwane obawy przed grożącą śmiercią, wzbudzają w ludziach tendencję do stereotypizacji (Pyrkosz, 2010, ss. 337-338). Z pewnością stereotypowemu spostrzeganiu innych sprzyjają mass media, gdzie w gazetach i programach telewizyjnych zwykle redaktorzy skupiaja się na skrajnych zachowaniach imigrantów. Znacznie rzadziej spotykamy się z informacjami na temat ich zwyczajnego życia, codziennych problemów (Marmola i in., 2013, s. 141).

Polska reakcja na falę imigrantów „szturmujących” Europę dokonywała się w okresie kampanii wyborczej na przełomie 2015 i 2016 r. Poprzednia ekipa rządząca pod kierownictwem pani premier Ewy Kopacz przyjęła liczbę imigrantów stanowiącą limit zaproponowany przez szefa Komisji Europejskiej Jean-Claude’a Junckera. Jednocześnie po jesiennych wyborach w Polsce władzę przejęła zwycięska partia Jarosława Kaczyńskiego. Nowym premierem została pani Beata Szydło. Po przejęciu w Polsce samodzielnej władzy przez Prawo i Sprawiedliwość diametralnie zmieniła się optyka postrzegania problemu imigrantów w Europie. Stanowisko Polski sprowadza się do następującego wniosku: mimo tego, że Polska zobowiązała się do przyjęcia kilku tysięcy migrantów w ramach unijnego programu relokacji, Polska nie może doprowadzić do sytuacji, żeby wydarzenia do których dochodzi w krajach Europy Zachodniej, przeniosły się na terytorium Polski. Dla gabinetu premier Beaty Szydło najważniejsze było bezpieczeństwo Polaków (Janik, Jaremczuk, 2017, s. 58).

Polska nie należy z pewnością do państw bezpośrednio zagrożonych atakami terrorystycznymi. Polska jest krajem jednolitym kulturowo i rasowo (Htawko, 2018, ss. 432-434). Społeczeństwo polskie cechuje zasadniczo homogeniczność etniczna. Choć w Polsce aktualnie zamieszkują przedstawiciele 9 mniejszości narodowych i 4 mniejszości etnicznych, to ich udział w ogólnej populacji jest niewielki (Leszkowicz-Baczyński, 2018, s. 4). Polska też ma o wiele mniej migrantów starających się o azyl niż inne państwa UE. Poza tym większa część z uchodźców 
traktuje Polskę jako przystanek do Zachodniej czy Północnej Europy, gdyż Polska nie jest atrakcyjnym krajem dla uchodźców w porównaniu z innymi krajami UE (Balicki, 2012, ss. 207-219).

Pewne jest więc, że Polska nie jest celem ataków terrorystycznych. ABW w swoich dorocznych raportach zaświadcza, że zagrożenie terroryzmem w naszym kraju jest niskie. Analizując zjawisko terroryzmu w Polsce, w kontekście istnienia zagrożenia wewnątrzpaństwowego, należałoby uznać, że jest ono dość znikome. Na obszarze naszego państwa nie odnotowano dotąd żadnej aktywnej działalności grupy zbrojnej z jakąkolwiek z islamskich organizacji terrorystycznych (Htawko, 2018, s. 434).

Propozycja solidarnego przyjmowania uchodźców przez kraje zachodnie UE silnie podzieliła polskie społeczeństwo na zwolenników i przeciwników pomagania ofiarom kryzysu. Od maja 2015 r. Centrum Badania Opinii Społecznej regularnie przeprowadzało sondaże, w których Polakom zadawane były pytania dotyczące ich stosunku do udzielania schronienia uchodźcom. Badano zarówno nastawienie do uchodźców w ogóle, jak i do konkretnych grup - pytano o osoby przybywające do Polski z Ukrainy, Bliskiego Wschodu, Afryki. Na przestrzeni roku, w którym prowadzono badania, postawy Polaków wobec uchodźców zmieniły się diametralnie. W pierwszym z tej serii sondaży CBOS aż $72 \%$ osób zadeklarowało poparcie dla przyjmowania uchodźców z krajów objętych konfliktami zbrojnymi (Jaremczuk, 2017, s. 171).

Wraz z narastającą kampanią mediów akceptacja dla przyjmowania uchodźców w Polsce stopniowo zmniejszała się. W lutym 2016 r. osiągnęła poziom najniższy - ledwie 39\% badanych zgadzało się na pomoc. Spośród nich tylko $4 \%$ opowiadało się za przyjmowaniem uchodźców i zezwalaniem na ich osiedlanie się w Polsce, 35\% aprobowało pomoc tymczasową - do czasu, kiedy uchodźcy będą mogli wrócić do swoich krajów pochodzenia. Aż 57\% ankietowanych uważało, że uchodźców nie powinniśmy przyjmować wcale. W miarę pogłębiania się tzw. kryzysu migracyjnego wskaźnik spadał do coraz niższego poziomu, a postawy polskich ankietowanych stawały się coraz bardziej wrogie. Poparcie dla przyjęcia uchodźców spadło do $26 \%$, a sprzeciw wzrósł do $67 \%$. Osoby najmłodsze przeciwstawiały się wszelkim formom pomocy częściej niż ludzie po 44 roku życia. Szczególnie radykalne postawy zajmowali reprezentanci najmłodszej z badanych grup wiekowych, czyli grupy obejmującej osoby mające od 18 do 24 lat. Podobnie osoby z wykształceniem podstawowym, gimnazjalnym lub zawodowym były częściej przeciwne przyjmowaniu uchodźców niż osoby ze średnim lub wyższym wykształceniem. W końcu 58\% osób identyfikujących się z prawicowymi opcjami politycznymi, $52 \%$ z centrowymi i $43 \%$ z lewicowymi popierało zamknięcie granic przed uchodźcami (Jaremczuk, 2017, ss. 171-172). 
Zapatrywania Polaków na możliwość przyjęcia uchodźców z Bliskiego Wschodu i Afryki Południowej przedstawiały się zupełnie inaczej niż ich zapatrywania na możliwość ugoszczenia uchodźców z Ukrainy. W pierwszych badaniach z 2015 r. przyjmowanie uchodźców z Ukrainy popierało 50\% osób, 38\% zaś było temu przeciwnych. Poparcie dla uchodźców w tym kontekście szybko wzrosło do $61 \%$ i od tej pory utrzymuje się na podobnym poziomie. Badani w odpowiedzi skąd bierze się niechęć Polaków do przyjmowania uchodźców z Bliskiego Wschodu i Afryki podkreślali odmienność religijną i kulturową cudzoziemców (Jaremczuk, 2017, s. 173).

W dniach 15-19 stycznia 2016 r. Dom Badawczy Maison przeprowadził badania ankietowe dla Związku Przedsiębiorców i Pracodawców pt. „Postawy Polaków względem przyjmowania imigrantów" na próbie ogólnopolskiej 1268 osób dobranych na Panelu Ariadna. Wyniki pomiaru różnią się w stosunku do wyników badań przeprowadzonych przez Fundację CBOS, ponieważ na pytanie: „Czy według Ciebie Polska powinna przyjmować imigrantów?", 68\% badanych była przeciwna, a 27\% respondentów odpowiedziała na „tak”; $7 \%$ wskazała odpowiedź „trudno powiedzieć" (Mróz, Ziółkowska-Weiss, 2017, s. 137).

Od 1 listopada 2015 r. do 31 stycznia 2016 r. Franciszek Mróz i Kamila Ziółkowska-Weiss z Uniwersytetu Pedagogicznego w Krakowie przeprowadzili badania ankietowe na grupie 1087 osób - wybranej próbie 407 studentów 4 szkół wyższych w Małopolsce oraz wybranej próbie 680 uczniów 5 szkół ponadgimnazjalnych w województwie małopolskim i podkarpackim. Celem przeprowadzonych badań było poznanie stanowiska młodzieży polskiej wobec problemu uchodźców. Interesująco przedstawiają się odpowiedzi na pierwsze pytania postawione w kwestionariuszu ankiety: „Czy mając prawo do decydowania, zgodził(a)by się Pan(i) na przyjęcie uchodźców do Polski?”, na które respondenci mogli udzielić odpowiedź z 7 możliwości podanych w kwestionariuszu ankiety. Niemal 70\% badanych zadeklarowała, że nie zgodziłaby się na przyjęcie uchodźców do Polski, z czego $27 \%$ respondentów zdecydowanie nie zaakceptowałaby takiego rozwiązania. Nieco ponad $20 \%$ ankietowanych popiera udzielenie pomocy uchodźcom, a 9,4\% nie zajęła w tym zakresie stanowiska. W porównaniu szczegółowego rozkładu odpowiedzi wśród młodzieży szkolnej i akademickiej wyraźnie zaznacza się bardziej negatywne nastawienie do uchodźców wśród studentów - ponad 81\% negatywnych odpowiedzi (Mróz, Ziółkowska-Weiss, 2017, s. 137).

Na pytanie: „Czy mając odpowiednie możliwości finansowe, socjalne, mieszkaniowe itp. zgodził(a)by się Pan/Pani na przyjęcie rodziny uchodźców we własnym mieszkaniu/domu?", respondenci udzielili w zdecydowanej większości negatywnej odpowiedzi. Niemal $80 \%$ badanych odpowiedziało, że nie zgodziłoby 
się na przyjęcie uchodźcy w swoim domu, a ponad $1 / 3 \mathrm{w}$ tej grupie wyraziła zdecydowany sprzeciw. Podobnie jak w przypadku odpowiedzi na pierwsze pytanie, również w tym przypadku w zestawieniu odpowiedzi odnotowano wyraźne różnice między młodzieżą akademicką a młodzieżą uczęszczającą do szkół ponadgimnazjalnych. Wśród badanej grupy studentów odsetek odpowiedzi negatywnych jest znacznie wyższy od uczniów szkół ponadgimnazjalnych. W grupie studentów tylko 29 osób, tj. 7,37\%, ugościłoby imigrantów w swoim mieszkaniu, w grupie uczniów szkół gimnazjalnych natomiast odsetek ten jest znacznie wyższy i wynosi 17\%. Wyraźnie pozytywniejsze odpowiedzi respondentów padły na pytanie: „Czy gdyby był/a Pan/i przedsiębiorcą, zatrudnił(a)by Pan/Pani uchodźcę w swojej firmie?”. Ponad 37\% badanych zdecydowałoby się na takie zatrudnienie, a przeciwnym takiemu rozwiązaniu jest nieco mniej niż połowa ankietowanych $-48,7 \%$. Również w tym przypadku studenci okazali się bardziej negatywnie nastawieni do uchodźców z perspektywy przedsiębiorcy niż młodzież szkół ponadgimnazjalnych (Mróz, Ziółkowska-Weiss, 2017, ss. 142-144).

$\mathrm{Z}$ odpowiedzi udzielonych przez respondentów na kolejne pytanie wynika, że dokładnie $40 \%$ badanych zgodziłaby się, aby po sąsiedzku zamieszkała rodzina uchodźców, a przeciwnym takiemu rozwiązaniu jest mniej niż połowa ankietowanych, tj. 46,54\%. Nastawienie uczniów szkół ponadgimnazjalnych do takiej sytuacji jest także wyraźnie pozytywniejsze niż w przypadku młodzieży akademickiej. Na pytanie: „Gdzie Pana/Pani zdaniem powinni mieszkać uchodźcy?”, respondenci mogli wskazać jedną z 5 zaproponowanych odpowiedzi, przy czym w przypadku odpowiedzi „w innych miejscach” mogli wpisać własną propozycję. Tę ostatnią możliwość odpowiedzi wybrało 135 badanych (12,7\% ogółu), a najczęstszymi zapisami były słowa: „u siebie w kraju”, „w swoim kraju”, „byle nie w Polsce”, „nigdzie”, „w Niemczech”, „powinni wrócić do swojego kraju i tam stworzyć sobie warunki mieszkaniowe". Tylko 6,8\% badanych wskazało, że przestrzeń, w której powinni mieszkać uchodźcy, jest zupełnie otwarta. Ponad 40\% respondentów wskazało, że uchodźcy powinni mieszkać w ośrodkach dla uchodźców, a niemal $1 / 4$ badanych, że w wydzielonych miejscach. Warto podkreślić, że głosy studentów i młodzieży szkolnej rozłożyły się bardzo podobnie - i tak na „ośrodki dla uchodźców" wskazało 45,89\% studentów i 37,86\% uczniów szkół ponadgimnazjalnych, „na wydzielone miejsca” - odpowiednio 21,59\% i 25,79\%, na „wszędzie” - odpowiednio 5,24\% i 7,69\%, na „w innych miejscach" natomiast - 15,21\% studentów i 15,38\% uczniów (Mróz, Ziółkowska-Weiss, 2017, ss. 144-145).

Równie interesująco przedstawiają się rozkłady odpowiedzi na kolejne dwa pytania: „Czy zna Pan/Pani osobiście uchodźcę, czyli osobę, która opuściła swój kraj w obawie przed prześladowaniem lub z powodu wojny?” oraz „Czy zdecy- 
dowałby się Pan(i) na pracę jako wolontariusz w ośrodku dla uchodźców”. Tylko 5,21\% badanych wskazało, że poznała osobiście uchodźcę. Z kolei $27 \%$ respondentów zdecydowałoby się na wolontariat w ośrodku dla uchodźców, przy czym młodzież z szkół ponadgimnazjalnych wykazała nieco większą gotowość na takie działanie - 28,7\% odpowiedzi na „tak” niż studenci wybranych szkół - 23,1\% udzieliło odpowiedzi na „tak”. Warto podkreślić, że kobiety ponad trzykrotnie częściej deklarowały gotowość podjęcia wolontariatu w ośrodkach dla uchodźców niż mężczyźni. Odsetek dla kobiet wyniósł 29,4\% ogółu badanych kobiet; odsetek dla mężczyzn - 7,9\% ogółu badanych mężczyzn (Mróz, Ziółkowska-Weiss, 2017, s. 146).

Na kolejne pytanie: „Co Pana/Pani zdaniem władze rządowe lub inne organizacje powinny zrobić dla uchodźców, którzy chcieliby pozostać w Polsce na stałe lub na więcej niż rok", uczniowie i studenci mogli wskazać kilka z 9 zaproponowanych odpowiedzi. Wskazania młodzieży szkolnej oraz studentów rozłożyły się bardzo podobnie, za wyjątkiem odpowiedzi „zapewnić mieszkanie” oraz „trudno powiedzieć”. Respondenci najczęściej wskazali następujące odpowiedzi: „zapewnić pobyt w ośrodku dla uchodźców” - 523 wskazania, tj. 22,6\% ogółu, „zorganizować kursy języka polskiego” - 507 wskazań, „pomoc w uzyskaniu pracy” - 396 wskazań oraz „zapewnić możliwość nauki zawodu” - 325 wskazań. Tylko 21 respondentów uważa, że władze powinny nadać uchodźcom obywatelstwo, a 99 wskazania - 4,29\% - dotyczyły „umożliwienia sprowadzenia rodziny”. Zaskakujące są niektóre odpowiedzi respondentów, które wpisano w rubryce „inne”, jak np.: „najlepiej, żeby ich nie było”, „powinni ich wyrzucić, szkoda pieniędzy”, „najlepiej nic”, „aby wrócili do swojego kraju”, „niech wracają z powrotem”, „zapewnić bezpieczny powrót”, „absolutnie nic”, „nie pomagać, bo Polakom podczas wojny nikt nie pomagał”, „szkolenia o polskim prawie i tradycji”, „powinni im pomóc wrócić do kraju” (Mróz, Ziółkowska-Weiss, 2017, s. 147).

Ponad $83 \%$ badanych dostrzega zagrożenia wynikające z przyjmowania uchodźców do naszego kraju. Respondenci najczęściej wskazywali (możliwość wskazań kilku z 9 zaproponowanych odpowiedzi): „powstają na tle rasowym i narodowościowym” - 645 wskazań, „pomoc dla uchodźców odbywa się kosztem Polaków” - 782 wskazania, „Wzrasta przestęppczość” - 589 wskazań oraz „rośnie bezrobocie”. Z kilkudziesięciu wyborów odpowiedzi „inne” warto przytoczyć kilka przykładów, które skłaniają do dalszych głębszych analiz socjologicznych: „zagrożenie bezpośrednie życia”, „nie stać nas na przyjmowanie uchodźców. Polacy nie mają gdzie mieszkać, a oni dostają mieszkania i zasiłki? Też chce być uchodźcą”, „zagrożenie atakami terrorystycznymi”, „nie szanują religii i kultury, a chcą by inni szanowali ich” (Mróz, Ziółkowska-Weiss, 2017, ss. 148-149). 
Dnia 20 czerwca 2018 r. premier Mateusz Morawiecki ogłosił, przyjętą wraz z innymi państwami Grupy Wyszehradzkiej, decyzję o odmowie udziału w nadzwyczajnym spotkaniu Komisji Europejskiej poświęconym relokacji migrantów. W 2017 r. zakończył się program przymusowej relokacji uchodźców w Unii Europejskiej. W dniach 7-14 czerwca 2018 r. Centrum Badania Opinii Społecznej przeprowadziło badanie „Aktualne problemy i wydarzenia” metodą wywiadów bezpośrednich wspomaganych komputerowo na liczącej 989 osób reprezentatywnej próbie losowej dorosłych mieszkańców Polski, w którym zadawano pytania dotyczące stosunku Polaków do przyjmowania uchodźców z krajów objętych konfliktami zbrojnymi - zarówno muzułmańskich, jak i sąsiadujących z Polską. $\mathrm{Z}$ przeprowadzonych badań wynika, że $60 \%$ Polaków było przeciwnych napływowi migrantów do naszego kraju. Niemal 1/3respondentów - 29\% - deklarowała, że powinniśmy przyjmować uchodźców do czasu, kiedy będą mogli wrócić do kraju pochodzenia, a co 20 , co stanowi zaledwie 5\% badanych, był zdania, że powinniśmy pozwolić na swobodne przebywanie i osiedlanie się uchodźców (Bożewicz, 2018, s. 2).

W porównaniu z październikiem 2017 r. zdecydowanie zmalał sprzeciw z 52\% do 46\% dotyczący wyraźnej dezaprobaty wobec przyjmowania uchodźców z Bliskiego Wschodu i Afryki przybywających do Europy. Ogółem niemal 3/4 Polaków, tj. 72\%, było niechętnych relokacji uchodźców spoza Europy, a nieco więcej niż co $5-22 \%$ respondentów - zaliczało się do zwolenników przyjmowania migrantów napływających do Unii Europejskiej. Dezaprobatę wobec przyjmowania przez Polskę uchodźców spoza Europy częściej niż pozostali wyrażało 82\% najmłodszych ankietowanych w wieku od 18 do 24 lat. Porównywalne odsetki przeciwników udzielenia schronienia migrantom z Bliskiego Wschodu i Afryki były wśród pracowników usług $-81 \%$, robotników wykwalifikowanych $-83 \%$ i niewykwalifikowanych $-88 \%$, badanych pracujących w prywatnych gospodarstwach rolnych $-84 \%$ oraz respondentów o poglądach prawicowych $-84 \%$. Jak wynika z badań otwarcie na przyjęcie migrantów było relatywnie większe wśród mieszkańców największych miast, 41\% z nich popierało relokację uchodźców do Polski, kadry kierowniczej i specjalistów z wyższym wykształceniem - 37\%, osób o miesięcznych dochodach per capita powyżej $1800 \mathrm{zł}-32 \%$, nieuczestniczących w praktykach religijnych $-33 \%$, a także identyfikujących się z lewica - 44\%. Brak zdania na ten temat częściej niż pozostali deklarowali renciści oraz ci, którzy nie potrafili jednoznacznie określić swoich poglądów politycznych - po 13\% (Bożewicz, 2018, ss. 3-4).

Zupełnie inaczej kształtował się stosunek Polaków do udzielenia azylu Ukraińcom z terenów objętych konfliktem zbrojnym. Ponad połowa badanych, tj. 56\%, 
opowiada się za przyjęciem uchodźców z sąsiedniego kraju, a nieco ponad 1/3, tj. 35\%, wyraża sprzeciw. Niechętny stosunek do przyjmowania przez Polskę uchodźców z Ukrainy deklarowali najczęściej mieszkańcy wsi - 43\%, respondenci gorzej wykształceni - 46\%, pracownicy usług - 45\%, robotnicy niewykwalifikowani - 59\%, badani o dochodach poniżej 900 zł na osobę w gospodarstwie domowym - 47\% oraz ci, którzy oceniają własne warunki materialne jako złe - 55\%. Przychylne stanowisko prezentowali natomiast badani najlepiej zarabiający - 74\%, mieszkańcy miast liczących 500 tysięcy i więcej ludności - 75\%, kadra kierownicza i specjaliści z wyższym wykształceniem - 78\% oraz uczniowie i studenci - 74\% (Bożewicz, 2018, s. 7).

\section{Zakończenie}

Problemem dla naszego narodu nie jest imigracja jako taka, ale to, kim są i jacy są imigranci. Imigracja z tego samego lub bliskiego kulturowo obszaru to bowiem coś zupełnie innego niż imigracja mas ludzi z obcych kultur. Obecny kryzys umożliwił odblokowanie w miarę szerszej dyskusji na temat imigracji, również w krajach, gdzie była ona od dawna odgórnie tamowana (Janik, Jaremczuk, 2017, s. 59). Polacy nie są mentalnie przygotowani na fakt, że do Europy przybywają uchodźcy i że wcześniej czy później zaczną przybywać też do Polski. Mamy dużo do zrobienia w tym względzie, zbyt wolno oswajamy się z pojawieniem się wśród nas ludzi innych kultur, innych wyzwań (Jaremczuk, 2017, s. 155).

\section{Bibliografia:}

Balicki, J. (2012). Imigranci i uchodźcy w Unii Europejskiej. Humanizacja polityki imigracyjnej i azylowej. Warszawa: UKSW.

Bożewicz, M. (2018). Stosunek Polaków i Czechów do przyjmowania uchodźców. Warszawa: Fundacja Centrum Badania Opinii Społecznej.

Dutka, G. (2017). Polacy w obliczu współczesnych procesów i problemów migracyjnych. Poczucie zagrożenia i jego społeczno-demograficzne uwarunkowania na podstawie analizy wyników badań sondażowych, Opuscula Sociologia, 4, 67-80. DOI: 10.18276/ os.2017.4-05.

Fehler, W., Cebul, K., Podgórzańska, R. (2017). Migracje jako wyzwanie dla Unii Europejskiej. Warszawa: Difin.

Hryniewicz, J. (2005). Uchodźcy w Polsce - teoria a rzeczywistość. Toruń: Adam Marszałek.

Htawko, P. (2018). Współczesne zagrożenia dla bezpieczeństwa Polski w przypadku przyjęcia uchodźców z Bliskiego Wschodu. W: H. Chałupczak, M. Lesińska, E. Pogo- 
rzała, T. Browarek (red.). Polityka migracyjna w obliczu wspótczesnych wyzwań. Teoria i praktyka (ss. 423-440). Lublin: UMCS.

Janik, E., Jaremczuk, E.J. (2017). Niekontrolowana migracja jako zagrożenie dla Europy - polski strach przed uchodźcami. W: E.J. Jaremczuk (red.). Migracje i kryzys uchodźczy w Europie. Rzeczywistość i wyzwania (ss. 11-68). Poznań: Wydawnictwo Naukowe FNCE.

Jaremczuk, E.J. (2017). Imigranci masowo napływający do krajów Unii Europejskiej potencjalnym zagrożeniem dla elblążan. W: E.J. Jaremczuk (red.). Migracje i kryzys uchodźczy w Europie. Rzeczywistość i wyzwania (ss. 155-178). Poznań: Wydawnictwo Naukowe FNCE.

Leszkowicz-Baczyński, J. (2018). Ewolucja przekonań Polaków wobec „obcych” jako efekt kryzysu migracyjnego w Europie, COLLOQUIUM, 2, 31-48.

Łodziński, S. (2012). Przymus dziejowy i poczucie ciągłości. Społeczno-kulturowy kontekst kształtowania się polityki migracyjnej w Polsce w latach 1918-2004. W: H.P. Müller, M. Zielińska (red.). Transgraniczność w perspektywie socjologicznej. Migracje przymusowe w Europie (ss. 67-92). Zielona Góra: Lubuskie Towarzystwo Naukowe.

Łodziński, S. (2017). Migracyjna „panika moralna”? Polska opinia publiczna wobec udzielania pomocy uchodźcom w okresie maj-grudzień 2015. W: J. Balicki, W. Necel (red.). Kryzys migracyjny w Europie. Wyzwania etyczne, spoteczno-kulturowe i etniczne (ss. 155-174). Warszawa: UKSW.

Marmola, M., Ochojska, D., Wańczyk-Welc, A. (2013). Postawy studentów wobec uchodźców. W: S. Pelc (red.). Wartości etyczne w pracy z uchodźcami (ss. 129-154). Rzeszów: Wyższa Szkoła Inżynieryjno-Ekonomiczna.

Mróz, F., Ziółkowska-Weiss, K. (2017). Młodzież szkolna i akademicka w Polsce wobec problemu uchodźców. W: J. Balicki, W. Necel (red.). Kryzys migracyjny w Europie. Wyzwania etyczne, spoteczno-kulturowe i etniczne (ss. 135-154). Warszawa: UKSW.

Olszewska-Łabędź, B. (2018). Kwestia pobytu uchodźców na terytorium polski w kontekście ochrony bezpieczeństwa publicznego. W: H. Chałupczak, M. Lesińska, E. Pogorzała, T. Browarek (red.). Polityka migracyjna w obliczu wspótczesnych wyzwań. Teoria i praktyka (ss. 369-384). Lublin: UMCS.

Pędziwiatr, K. (2014). Imigranci w Polsce i wyzwania integracyjne, Studia BAS, 4, ss. 135-153 .

Podgórzańska, R. (2015). Problem polityzacji zjawiska migracji w powojennej Polsce. W: B. Kromolicka, H. Walczak (red.). Bezdomna Europa. Migracje po II wojnie światowej we wspótczesnych badaniach humanistów (ss. 233-253). Szczecin: Minewra.

Pyrkosz, J., Kossowska, M. (2010). Gdzie dosięga nas terroryzm. Wpływ poczucia zagrożenia terroryzmem na postawy narodowe i postawy wobec emigrantów z Polski mieszkających w Wielkiej Brytanii oraz Polaków przebywających w Polsce. W: H. Grzymała-Moszczyńska, A. Kwiatkowska, J. Roszak (red.). Drogi i rozdroża. Migracje Polaków w Unii Europejskiej po 1 maja 2004 (ss. 337-343). Kraków: Nomos.

Wach, D. (2018). Ewolucja polskiej polityki integracji cudzoziemców po 1989 roku. W: H. Chałupczak, M. Lesińska, E. Pogorzała, T. Browarek (red.). Polityka migracyjna w obliczu wspótczesnych wyzwań. Teoria i praktyka (ss. 347-368). Lublin: UMCS. 
Ząbek, M., Łodziński, S. (2008). Uchodźcy w Polsce. Próba spojrzenia antropologicznego. Warszawa: Aspra-JR.

Zielińska, I. (2004). Media, interes i panika moralna nowa kategoria socjologiczna i jej implikacje, Kultura i Spoteczeństwo 3, 161-177. 